potential sales through motives of market participants and their purchasing (bandwidth) capacity. This is the fundamental part of marketing activities, its internal component, which determines directly the parameters of the material flows in the process of marketing activity of the enterprises of the textile industry.

As a result of market research in the textile industry appeared unlimited opportunities to gain the leading position in the world textile export market of textile products especially finished products. In the structure of exports of textile products in 2014 the share of yarn is $58 \%$; the finished product $-25 \%$; fabric $-7 \%$; knitted fabric $-5.2 \%$ and the production of silk is $2.8 \%$ [2].

Exports textile enterprises of the Republic has increased significantly not only volumes, but also increased the number of exported countries as well as exporters of total exports, for example, if in 2013 the share of new exporters was $5.3 \%$, while in 2014 this figure is expected to reach 8.4 per cent. For the period from 2011 by 2013 , the number of exporters has increased from 123 to 250 companies. If the rate of growth of exports in 2010 amounted to $160 \%$, in 2013 amounted to $183 \%$ [3].
In the period 2013-2014, exploited markets of 48 countries, including 5 new market, Hungary, Sri Lanka, Kenya, Morocco and Tunisia. Also mastered such remote countries as Argentina, Brazil, Venezuela, Colombia, Peru, Chile, and South Africa. Currently the company has created more than 60 dealer units exporters in the EU, CIS and Asia [5].

Conclusion: In our opinion, the organization of marketing activities in enterprises of the textile industry should be based on the following activities:

- building an organizational structure marketing management;

- selection of marketing professionals who are duly qualified;

- creation of conditions for effective work of employees of the marketing department;

- organization of effective interaction of marketing with other services companies.

Thus, the organization of marketing activities for the above described activities will enable the textile industry to improve production efficiency and be able to maintain its position in the commodity market.

\title{
References:
}

1. Muminova N. Stimulation of demand competitive textile products.//Federation Journal. Russia. - 2014. - No. 1-2.

2. Madjidov Sh., Khakimov B. Viewpoints about potential stimulation and possibilities of investments on textile industry of Uzbekistan.//European journal of business and economics. - Volume 6. - 2012. - P. 22-24.

3. Madjidov Sh., Khakimov B. About investment condition of silk branch.//European Applied Sciences. Journal. Shtutgart, Germany: ORT Publishing, - 2014. - No. 7.

4. Muminova N. The objectives of the development of marketing services in the trade of textile products. The monograph “IQTISOD va MOLIYA". - Tashkent, 2013. - 200 p.

5. [Electronic resource]. - Available from: htpp://www.legprom.uz.

Starkova Nadezhda Olegovna,

Kuban State University,

candidate of science in Economics, associate professor, International economics

and management department

E-mail:n.starkova@mail.ru

Buchina Elena Vasilievna,

Kuban State University,

undergraduate of International economics

and management department

E-mail:korolevi4na90@mail.ru

\section{Features of forming of brand of Krasnodar Region}

\begin{abstract}
Rising role of branding of territories in management of socio-economic development of regions has been estimated. Most favorable conditions for the formation of an effective brand in the region have been determined. Unique advantages of Krasnodar region, as one of most promising and attractive for tourists, businessmen
\end{abstract}


and investors Russian regions have been characterized. Proposals for organization of brand management and brand development of Krasnodar region have been formed.

Keywords: brand, branding, region, Kuban, Krasnodar region, natural and climatic factors, intellectual assets, marketing.

Старкова Надежда Олеговна, Кубанский государственньй университет, кандидат экономических наук, дочент кафедры мировой экономики и менеджмента

E-mail:n.starkova@mail.ru

Бучина Елена Васиивевна,

Кубанский государственный университет, магистрант кафедры мировой экономики и менеджмента

E-mail: korolevi4na90@mail.ru

\section{Особенности формирования бренда Краснодарского Края}

Аннотация: Оценена повышающаяся роль брендинга территорий в управлении социально-экономическим развитием регионов. Определены наиболее благоприятные условия формирования эффективного бренда региона. Охарактеризованы уникальные преимущества Краснодарского края, как одного из наиболее перспективных и привлекательных Аля туристов, бизнесменов и инвесторов регионов РФ. Внесены преАложения по организации процесса управления и развития бренда Краснодарского края.

КАючевые слова: бренА, брендинг, регион, Кубань, Краснодарский край, природно-климатические факторы, интемлектуальные активы, маркетинг.

Вопросы формирования бренда российских регионов на протяжении Алительного времени достаточно активно обсужАаются преАставителями феАерального и региональных органов вцасти, а также научной общественностью и практиками в области экономики, управления и маркетинга. Многочисленные исскедования понятия, сущности и особенностей брендинга территорий подтвержАают, что на сегоАняшний день он явмяется самостоятельным научнообоснованным методом управления социально-экономическими процессами развития региона $[4 ; 6]$. Учитывая то, что бренд территории активно эксплуатирует при позиционировании конкретного региона именно его уникальные особенности [8] и искмючительные преимущества в его формировании должны быть заинтересованы в первую очередь те регионы, которые располагают особенным географическим положением [13], природными ресурсами, природноклиматическими условиями, облаАают исторической важностью Аля страны, высоким интемлектуальным потенциалом [9], кумьтурными, историческими, этническими достопримечательностями, особым творческим наследием и т. А. Все эти преимущества в совокупности отражаются на качестве производимых в Аанной местности товаров и ускуг и обуславливают наличие их отличительных особенностей [2].
Учитывая данные обстоятельства одним из наиболее перспективных с точки зрения наличия уникальных факторов Аля формирования и развития своего бренда является Краснодарский край. Регион, занимающий по площади 76 тыс. квадратных километров, обладает уникальным географическим положением, имея достаточно протяженную береговую минию Черного и Азовского моря, горы, равнины и меса с уникальным аля России климатом. От ААлера Ао Туапсе сформировался единственный в РФ регион влажных субтропиков. Климат побережья от Туапсе Ао Анапы средиземноморский. Его различие от субтропиков заключается в более низких зимних температурах и меньшим количеством осадков. КАимат Азовского побережья умеренно континентальный с чертами морского.

На сегодняшний Аень край, в силу многогранного географического расположения, предлагает различные виды товаров и ускуг отдыха, а также высокий интерес Аля развития бизнеса. Азово-Черноморское побережье явмяется курортно-рекреационным регионом. Черноморское побережье Краснодарского края является одним из наиболее крупных курортных районов РФ. К ним относятся города - курорты Сочи, Анапа, ГеменАжик, Туапсе бальнеологические курорты Ейск на Азовском море, Горячий КАюч в преАгорьях 
Западного Кавказа, а также горнокииматическая станция Красная Поляна. ВАоль побережья Чёрного моря и в прилегающих горных районах Западного Кавказа (в том числе по Кавказскому заповеАнику) проходят всероссийские туристские маршруты.

Помимо природно-климатических факторов Краснодарский край привлекателен Аля посетителей и бизнесменов своим богатым историко-культурным потенциалом. Известный этнографический музей «Атамань» находящийся на живописном на берегу Таманского залива, созданный из небольшой стани-

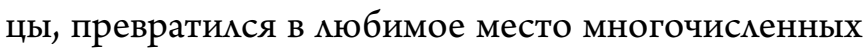
покцонников казачьего быта, что только благоприятным образом сказывается на экономическом состоянии всего Темрюкского района и формирует имиАж бренда казачьего края. Только открытие фестиваля « Аегенды Тамани» собирается Ао сорока тысяч гостей. В Анапе, находятся археологический музей Аревнего греческого посемения Горгиппия, существовавшего на месте современного города, и армянский культурный центр «Арин-БерА», который также ежегоАно привлекает большое число посетителей.

В настоящее время в Краснодарском крае сосреАоточено 1300 зАравниц и более 400 туристических преАприятий, в совокупности составмяющих $25 \%$ всего курортного комплекса РФ.Пансионаты и зАравницы Краснодарского края в период максимацьного развертывания) могут принимать 220 тысяч отАыхающих (это треть емкости всех курортов России). Частные минигостиницы в метнее время может принять около 200 тысяч неорганизованных (без путевок) отАыхающих. Рост спроса на туристские продукты и услуги региона в настоящее время происходит за счет повысившегося интереса гражАан к горнолыжному курорту Красной Поляне. Большую роль в Аанном процессе сыграло провеАение в Сочи в 2014 году Зимних Олимпийских игр, специально Аля которых было возведено множество инфраструктурных объектов, способных повысить уровень и качество туристских услуг. Также сами ОАимпийские объекты несут в себе символику побеАоносной Аля РФ ОАимпиаАы, бренА которой очень положительно воспринимается россиянами и высоко оценивается экспертами Ао сих пор. Это могмо бы быть использовано не только в позиционировании привлекательности города Сочи и курорта Красная Поляна, но и всего Краснодарского края. По мнению краевого Министерства курортов и туризма к 2015 гоАу, количество туристов в регион может Увеличиться Ао 16 млн. человек в гоА. Причинами тому могут служить макроэкономические и геополитические факторы, а также общее настроение населения россиян, резко сокративших количество зарубежных туристических поезАок в пользу путешествий внутри страны.

В сложившихся условиях ослабления курса рубля, высокого уровня инфмяции [11] и вынужденной изомяции российской экономики органам вмасти и преАпринимательскому сектору Краснодарского края необходимо наиболее серьезно отнестись к продвижению бренда региона, основанного на кубанском гостеприимстве, казачьих траАициях и уникамьных природно-кмиматических особенностях местности. Развитие брендинга и повышение уровня привлекательности преАприятий Краснодарского края в глазах возросших в период кризиса численно отечественных потребитекей туристских ускуг, позволит региону занять освободившуюся рыночную нишу, которая по всем законам маркетинга Аомжна быть заполнена как можно быстрее.

Амя успешной работы наА брендом преАставите-

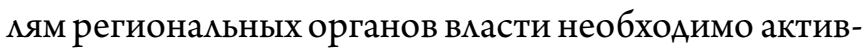
но участвовать в процессе созАания и эффективного использования всей совокупности информационно-интемлектуацьных факторов развития региона, осуществцяя эту Аеятельность в тесной взаимосвязи с представителями бизнеса, размичных общественных организаций, искусства и кумьтуры, туризма образования, зАравоохранения, СМИ. Аоказано, что уникальные интемлектуальные активы отАельной фирмы влияют на формирование ее рыночной стоимости $[7 ; 8]$, на этом основании можно предполагать, что системное управление этими активами на уровне региона Аолжно реализоваться в повышении его конкурентоспособности, инвестиционной привлекатемьности, росте стоимости капитализации активов регионамьной туристической инфраструктуры.

За счет инвестиций в бренА, мюбой регион в силах повысить свой экономический и интемлектуамьный статус $[3 ; 12]$. ВнеАрение таких прогрессивных метоАОв становится моАным тренАОм российской региональной политики [5]. БлагоАаря эффективной стратегии позиционирования и продвижения бренда, основанного на положительном имидже Краснодарского края, Аемонстрирующего Аостоинства и уникацьные особенности его местности и производимых на его территории товары и услуги, в крае может значительно повыситься уровень, качество жизни, Аоля участия в созАании ВВП, инвестиционная привлекательность [10] и т. А. 
Краснодарский край в настоящее время обладает большим потенциалом Аля развития, а также имеет грамотно сформулированную концепцию бренда Кубани, от развития и реализации которой зависят его экономические перспективы. Разработка и функционирование эффективной системы формирования и управления брендом Кубани может не только предоставить конкурентные преимущества местным товарам и ускугам на потребительском рынке, но также воздействовать на рост уровня инвестиционной привлекательности, увеличения потока обычных и деловых туристов, повышения конкурентоспособности региона, привмечения гражАан к восстановлению и сохранению исторических памятников, восстановлению и развитию культурных и учебных центров, прогрессивному интеммектуальному развитию и процветанию территории.

\section{Список митературы:}

1. Козырь Н. С., Полиди А.А. Теоретические основы управления капитализацией на основе реструктуризации.//Terra Economicus. - 2008. - Т. 6. - № 3-2. - С. 128-130.

2. Костарева А. М., Старкова Н. О. Особенности применения вирусного маркетинга в развитии рыночной Аеятельности современных преАприятий.//Политематический сетевой электронный научный журнал Кубанского государственного аграрного университета. - 2013. - № 04 (088). - С. $642-652$.

3. Куницына Н.Н., Савцова А. В. Региональные экономические системы: цикличность и неопределенность Аинамики (монография). - Ставрополь: Ставропольское книжное издательство, 2008. - 184 с.

4. Моисеева Н. Маркетинговая подАержка бренда./Н. Моисеева, И. Баринова//Маркетинг: методы, формы, модели. - 2010. - № 2 (111). - С. 39-50.

5. Никулина О.В. Маркетинг инновационного развития преАприятия.//Национальные интересы: приоритеты и безопасность. - 2010. - № 10. - С. 50-55.

6. Никулина О.В., Аарченко Е.С. Разработка инновационных маркетинговых технологий международных сбытовых компаний в вопросах увеличения доли рынка.//Экономика и предпринимательство. - 2013. № 2 (31). - С. 278-283.

7. Старкова Н.О. Формирование внутрифирменной системы управления интеммектуальными активами. [Текст]: Аис. канА. экон. наук: 08.00.05 - Краснодар, 2001. - 202 с.

8. Старкова Н. О., Подложнова Н. В. Предпосылки и особенности формирования бренда региона в РФ.//Экономика и управмение в XXI веке: тенденции развития. - 2015. - № 20. - С. 69-74.

9. Старкова Н. О., Тиминова Е. В. Организация маркетинга персонала на зарубежных и российских предприятиях.//Austrian Journal of Humanities and Social Sciences. - 2014. - № 3-4. - С. 250-254.

10. Старкова Н. О., Рзун И. Г., Саватеева А. С. Основные направления и проблемы привлечения иностранных инвестиций в РФ.//Современные тенденции в экономике и управлении: новый взгляА. - 2014. № 30. - С. 209-214.

11. Старкова Н. О., Рзун И. Г., Аверина А. В. Инфмяция на потребительском рынке. Оценка тенденций и перспектив.//Актуальные вопросы экономических наук. - 2014. - № 41-1. - С. 168-173.

12. Шаромов А. БренА региона - инструмент привлечения инвестиционных и политических ресурсов.//Европейская окраина: прикамский ежедневник. //[Экектронный ресурс]. - Режим доступа: http://eurokraina. $\mathrm{ru} /$ posts/view/376.

13. Шевченко И. В., Боштек А.А. Обоснованные риски преАприятий санаторно-курортного комплекса. Особенности оптимизации денежных потоков компании.//Экономика: теория и практика. - 2012. № $1(25)$. - C. 46-52. 